\title{
Chemical compositions, radical scavenging capacities and antimicrobial activities in seeds of Satureja hortensis L. and Mentha spicata L. subsp. spicata from Turkey
}

\author{
I. Emre $^{a}$ (D), M. Kurşat ${ }^{b *}$ (D), Ö. Yilmaz ${ }^{c}$ (D) and P. Erecevid (D) \\ a Department of Primary Education, Faculty of Education, Firat University, 23119, Elazig, Turkey \\ ${ }^{b}$ Department of Biology, Faculty of Sciences and Arts, Bitlis Eren University, 13100, Bitlis, Turkey \\ 'Department of Biology, Faculty of Science, Firat University, 23119, Elazig, Turkey \\ ${ }^{\mathrm{d}}$ Department of Biology, Faculty of Science, Munzur University, 62000, Tunceli, Turkey \\ *e-mail: botanikkursat@gmail.com
}

Received: May 30, 2019 - Accepted: September 19, 2019 - Distributed: February 28, 2021

\begin{abstract}
The present study determined some biological compounds, radical scavenging activity and antimicrobial capacity in seeds of Satureja hortensis L. and Mentha spicata L. subsp. spicata. Alpha-linolenic acid (C18:3 n3) has been found to be the major polyunsaturated fatty acid of Satureja hortensis L. (66.24 $\pm 1.24 \%)$ and Mentha spicata L. subsp. spicata $(48.17 \pm 1.01 \%)$. Linoleic acid (C18:2 n6) is identified as the second major polyunsaturated fatty acid in the present study and oleic acid (C18:1 n9) is determined as the major monounsaturated fatty acid. Current study showed that Satureja hortensis L. and Mentha spicata L. subsp. spicata have low levels of saturated fatty acids. It has been demonstrated that ergosterol $(263.1 \pm 2.14 \mu \mathrm{g} / \mathrm{g})$, stigmasterol $(39.07 \pm 0.91 \mu \mathrm{g} / \mathrm{g})$ and beta-sitosterol $(14.64 \pm 0.49 \mu \mathrm{g} / \mathrm{g})$ have been found in Mentha spicata L. subsp. spicata, while ergosterol $(69.41 \pm 1.75 \mu \mathrm{g} / \mathrm{g})$ and beta-sitosterol $(19.81 \pm 1.14 \mu \mathrm{g} / \mathrm{g}) \mathrm{have}$ been determined in Satureja hortensis L. Also, this study determined that Satureja hortensis L. and Mentha spicata L. subsp. spicata have low lipide-soluble vitamin content. Furthermore, it has been found that Satureja hortensis L. contains naringenin $(612.57 \pm 2.57 \mu \mathrm{g} / \mathrm{g})$, morin $(86.97 \pm 1.12 \mu \mathrm{g} / \mathrm{g})$, quercetin $(22.87 \pm 0.75 \mu \mathrm{g} / \mathrm{g})$, and kaempferol $(20.11 \pm 0.94 \mu \mathrm{g} / \mathrm{g})$ while naringenin $(135.91 \pm 1.91 \mu \mathrm{g} / \mathrm{g})$, naringin $(61.23 \pm 2.15 \mu \mathrm{g} / \mathrm{g})$ and quercetin $(47.51 \pm 1.17 \mu \mathrm{g} / \mathrm{g})$ have been detected as major flavonoids in the seeds of Mentha spicata L. subsp. spicata. The results of the present study suggest that methanol extracts of Satureja hortensis L. and Mentha spicata L. subsp. spicata have significant free radical scavenging activity. The present results revealed that Satureja hortensis L. and Mentha spicata L. subsp. spicata showed major activity against gram-positive and gram-negative microorganisms, fungi and yeast.
\end{abstract}

Keywords: antimicrobial activity, biocompounds, Mentha spicata L. subsp. spicata, radical scavenging activity, Satureja hortensis L.

\section{Composições químicas, capacidades radicais eliminadoras e atividades antimicrobianas em sementes de Satureja hortensis L. e Mentha spicata L. subsp. spicata da Turquia}

\begin{abstract}
Resumo
O presente estudo determinou alguns compostos biológicos, atividade de eliminação de radicais e capacidade antimicrobiana em sementes de Satureja hortensis L. e Mentha spicata L. subsp. spicata. O ácido alfa-linolênico (C18: 3 n3) foi o principal ácido graxo poliinsaturado de Satureja hortensis L. (66,24 $\pm 1,24 \%)$ e Mentha spicata L. subsp. spicata $(48,17 \pm 1,01 \%)$. O ácido linoléico (C18: 2 n6) é identificado como o segundo principal ácido graxo poliinsaturado no presente estudo e o ácido oleico (C18: 1 n9) é determinado como o principal ácido graxo monoinsaturado. O estudo atual mostrou que Satureja hortensis L. e Mentha spicata L. subsp. spicata tem baixos níveis de ácidos graxos saturados. Foi demonstrado que ergosterol $(263,1 \pm 2,14 \mu \mathrm{g} / \mathrm{g})$, estigmasterol $(39,07 \pm 0,91 \mu \mathrm{g} / \mathrm{g})$ e beta-sitosterol $(14,64 \pm 0,49 \mu \mathrm{g} / \mathrm{g})$ foram encontrados em Mentha spicata L. subsp. spicata, enquanto o ergosterol $(69,41 \pm 1,75 \mu \mathrm{g} / \mathrm{g})$ e beta-sitosterol $(19,81 \pm 1,14 \mu \mathrm{g} / \mathrm{g})$ também foram determinados em Satureja hortensis L., este estudo determinou que Satureja hortensis L. e Mentha spicata L. subsp. spicata tem baixo teor de vitaminas lipossolúveis. Além disso, verificou-se que S. hortensis L. contém naringenina $(612,57 \pm 2,57 \mu \mathrm{g} / \mathrm{g})$, morina $(86,97 \pm 1,12 \mu \mathrm{g} / \mathrm{g})$, quercetina $(22,87 \pm 0,75 \mu \mathrm{g} / \mathrm{g})$ e kaempferol $(20,11 \pm 0,94 \mu \mathrm{g} / \mathrm{g})$ enquanto a naringenina $(135,91 \pm 1,91 \mu \mathrm{g} / \mathrm{g})$, a naringina $(61,23 \pm 2,15 \mu \mathrm{g} / \mathrm{g})$ e a quercetina $(47,51 \pm 1,17 \mu \mathrm{g} / \mathrm{g})$ foram detectadas como flavonóides importantes nas sementes de Mentha spicata L. subsp. spicata. Os resultados do presente estudo sugerem que os extratos metanólicos de S. hortensis L. e Mentha
\end{abstract}


spicata L. subsp. spicata tem significativa atividade de eliminação de radicais livres. Os presentes resultados revelaram que Satureja hortensis L. e Mentha spicata L. subsp. spicata mostrou atividade importante contra microrganismos gram-positivos e gram-negativos, fungos e leveduras.

Palavras-chave: atividade antimicrobiana, biocompostos, Mentha spicata L. subsp. spicata, atividade de eliminação radical, Satureja hortensis L.

\section{Introduction}

Medicinal plants include a large variety of substances named phytochemicals that posses antioxidant activity (Giao et al., 2007; Tepe, 2008; Yesiloglu et al., 2013). Typical compounds that exhibit antioxidant activity comprise vitamins, carotenoids and phenolic compounds (Chanwitheesuk et al., 2005). Since synthetic antioxidants may lead to toxicity and carcinogenity interest in natural antioxidants has been rised last years (Pandini et al., 2018). Many herbs, particularly members of Lamiaceae family show strong antioxidant activity (Javanmardi et al., 2003).

Satureja, which is from Lamiaceae, is represented by 15 species of which the endemism ratio is 33\% in Flora of Turkey (Davis, 1982; Gören et al., 2003; Satil and Kaya, 2007). Many members of Satureja have aromatic and medicinal characteristics (Eminagaoglu et al., 2007; Abd El Tawab et al., 2014). The leaves, flowers and stems of Satureja are used for herbal tea and it has been reported that Satureja species posses antimicrobial, antifungal, antiinflammatory (Güllüce et al., 2003; Gören et al., 2003; Boroja et al., 2018). Mentha, the other genus studied, distributed thoroughout temperate regions of Eurasia, Australia and South Africa (Gulluce et al., 2007). The genus includes fifteen taxa belonging to eight species in the flora of Turkey (Aksit et al., 2013). Leaves, flowers and the stem of Mentha species are frequently used in herbal teas or as additives in commercial spice mixtures for many foods to offer aroma and flavour (Moreno et al., 2002; Gulluce et al., 2007). It has been reported that the aeiral parts of Mentha have tonics, antispasmodic, stomachic and anti-inflammatory effects in the traditional medicine (Benabdallah et al., 2016, 2018).

This is the report about fatty acid, vitamin, sterol, radical scavenging and antimicrobial activity in seeds of Satureja hortensis and Mentha spicata L. subsp. spicata. The goals of present study are i) to detect fatty acid compositions, vitamin and sterol contents; ii) to evaluate flavonoid contents and radical scavening properties in the seeds of Satureja hortensis and Mentha spicata L. subsp. spcicata; iii) in addition, the aim of this research is to investigate the antimicrobial activities of fatty acids, vitamins and flavonoid contents in the seeds which such a study has not been found in the literature.

\section{Material and Methods}

In the present study, Satureja hortensis (Elazı̆̆ Baskil-Bolucuk village, $1580 \mathrm{~m}$ ) and Mentha spicata L. subsp. spcicata (Elazı $\breve{g}$, Baskil-Bolucuk village, $1580 \mathrm{~m}$ ) taxa are collected from the natural habitats. The plant materials are deposited in Firat University Herbarium (FUH).

\subsection{Extraction of seed oils}

Seed materials have been finely ground in a mill and then extracted with hexane/isopropanol (3:2 v/v) (Hara and Radin, 1978). The lipid extracts have been centrifuged at $10.000 \mathrm{~g}$ for 5 minutes and filtered, and the solvent has been then removed on a rotary evaporator at $40{ }^{\circ} \mathrm{C}$. The extracted lipids have been stored under $-25^{\circ} \mathrm{C}$ until further analysis.

\subsection{Fatty acids analyses}

$2 \%$ sulphuric acid $(\mathrm{v} / \mathrm{v})$ in methanol has been used to obtain the fatty acid methyle esters in the lipid extracts based on Christie' (1990) method. The methyl esters have been separated and quantified by gas chromatography and flame-ionization detection (Shimadzu GC 17 Ver.3) coupled to a Glass GC 10 after the fatty acid methyl esters have been treated with n-hexane and. Chromatographical conditions have been done with a capillary column ( $25 \mathrm{~m}$ in length and $0.25 \mathrm{~mm}$ in diameter, Permabound 25, Macherey-Nagel, Germany) using nitrogen as a carrier gas (flow rate $0.8 \mathrm{~mL} / \mathrm{min}$.). The temperatures of the column, detector and injection valve are adjusted to 130-220, 240, and $280{ }^{\circ} \mathrm{C}$, respectively. It has been used authentic standart mixtures to obtain the methyle esters.

\subsection{Chromatographic analysis and quantification of lipid soluble vitamins and sterols}

Lipide-soluble vitamins and phytosterols have been extracted from the lipid fraction by the method of Sánchez-Machado et al. (2002) with minor modifications. The extracted lipids of seed material have been dissolved in acetonitrile/methanol (75/25 v/v) and have been injected $50 \mu \mathrm{L}$ to HPLC (Shimadzu, Kyota Japan). The used column is a Supelcosil ${ }^{\mathrm{TM}} \mathrm{LC} 18(250 \times 4.6 \mathrm{~mm}, 5 \mu \mathrm{m}$, Sigma, USA $)$ and the mobile phase is acetonitrile/methanol $(75 / 25, \mathrm{v} / \mathrm{v})$. The elution has been performed at a flow-rate of $1 \mathrm{~mL} / \mathrm{min}$ and the temperature of analytical column is kept constant at $40{ }^{\circ} \mathrm{C}$. the detection has been performed at $320 \mathrm{~nm}$ for retinol (vitamin A) and retinol acetate, and $215 \mathrm{~nm}$ for $\delta$-tocopherol, vitamin D, $\alpha$-tocopherol, $\alpha$-tocopherol acetate, $265 \mathrm{~nm}$ for vitamin $\mathrm{K} 1$ and $202 \mathrm{~nm}$ for phytosterols (López-Cervantes et al., 2006). Class Vp 6.1 software assisted at workup of the data. The results of analysis have been expressed as $\mu \mathrm{g} / \mathrm{g}$ for samples.

\subsection{Flavonoid analysis and DPPH (1,1-diphenyl-2- picrylhydrazyl) radical scavenging capacity}

\subsubsection{Preparation of the extracts}

Homogenization of two $\mathrm{g}$ seed materials is done in $5 \mathrm{~mL} 80 \%$ methanol. Homogenates have been centrifuged at $5000 \mathrm{rpm}$ at $+4{ }^{\circ} \mathrm{C}$. The supernatant is concentrated by 
reduced-pressure rotary evaporation after centrifugation. Each extract is re-suspended in dimethyl sulphoxide (DMSO) to produce a reserve solution (Kursat et al., 2011).

\subsection{Chromatographic conditions for flavonoids}

A PREVAIL C18 reversed-phase column $(15 \times 4.6 \mathrm{~mm}$, $5 \mu \mathrm{m}$, USA) is used to do chromatographic analysis and methanol/water/acetonitrile (46/46/8, v/v/v) containing $1.0 \%$ acetic acid has been used as the mobile phase ( $\mathrm{Zu}$ et al., 2006). The mobile phase has been filtered through a $0.45 \mu \mathrm{m}$ membrane filter (Millipore), then de-aerated ultrasonically prior to use. Catechin (CA), naringin (NA), kaempferol (KA), naringenin (NAR), resveratrol (RES), myricetin (MYR), morin (MOR), quercetin (QU) and rutin (RU) have been measured by DAD separation at $280 \mathrm{~nm}$ for CA and NA, $254 \mathrm{~nm}$ for RU, MYR, MOR and QU, $306 \mathrm{~nm}$ for RES, and $265 \mathrm{~nm}$ for KA. Flow rate and injection volume have been adjusted to $1.0 \mathrm{~mL} / \mathrm{min}$ and $10 \mu \mathrm{L}$, respectively. The chromatographic peaks of the extracts have been evaluated by comparing their retention time with that of the reference standards. All chromatographic operations have been done at a temperature of $25^{\circ} \mathrm{C}$.

\subsection{Antioxidant assay by DPPH radical scavenging activity}

The free radical scavenging effects of extracts have been measured by the decoloration of a methanolic solution of $\mathrm{DPPH}^{*}$ based on the Liyana-Pathirana and Shahidi' (2005) method. A solution of $25 \mathrm{mg} / \mathrm{L} \mathrm{DPPH}$ in methanol has been solved and $4.0 \mathrm{~mL}$ solution is mixed with 50,100 and $250 \mu \mathrm{L}$ of extract in DMSO. Then, mixture has been stored in darkness at room temperature for 30 minutes. The absorbance of the mixture has been evaluated spectrophotometrically at $517 \mathrm{~nm} .1 \mu \mathrm{M}$ quercetin is used as a reference (Kursat et al., 2011).

The scavenging capacity of DPPH radicals have been determined by the following Equation 1:

$$
\text { DPPH radical scavenging activity }(\%)=\begin{gathered}
{[(\text { Abs control }- \text { Abs sample })] /} \\
(\text { Abs control })] \times 100
\end{gathered}
$$

where: Abs control is the absorbance of DPPH radical + methanol; Abs sample is the absorbance of DPPH radical + sample extract/standard (Kursat et al., 2011).

\subsection{Antimicrobial activity}

\subsubsection{Test microorganisms}

4 bacteria (Escherichia coli ATCC 25922, Klebsiella pneumoniae FMC 5, Staphylococcus aureus COWAN 1, Bacillus megaterium DSM 32), 2 yeasts (Candida albicans FMC 17, Candida glabrata ATCC 66032) and 2 dermatophyte species (Trichophyton sp., Epidermophyton sp.) have been used in the present investigation. Microorganisms have been supplied from the Department of Biology, Firat University, Microbiology Laboratory, Elazig-Turkey.

\subsubsection{Antimicrobial activity}

Antimicrobial tests have been done by using the well agar method $\left(100 \mu \mathrm{L}\right.$ of suspension containing $10^{6}$ cells $/ \mathrm{mL}$ of bacteria, $10^{4}$ cells $/ \mathrm{mL}$ yeast and cell $\mathrm{s} / \mathrm{mL}$ dermatophyta fungi as per McFarland standard, inoculated into Mueller Hinton Agar (Difco), Malt Extract Agar (Difco), and Sabouroud Dextrose Agar (Oxoid), respectively). Wells have been prepared in the plates with the help cork-borer $(0.85 \mathrm{~cm}) .10 \mu \mathrm{L}$ of the flavonoids, vitamins and fatty acids in the seeds have been added in to the well. Steril petri dishes $\left(9 \mathrm{~cm}\right.$ diameter) have been placed at $4{ }^{\circ} \mathrm{C}$ for $2 \mathrm{~h}$. Then, the inoculated plates have been incubated at $37 \pm 0.1{ }^{\circ} \mathrm{C}$ at $24 \mathrm{~h}$ for bacterial strains and also at $25 \pm 0.1^{\circ} \mathrm{C}$ at $72 \mathrm{~h}$ for yeast and dermatophyta fungi. Antimicrobial activity has been observed by measuring the zone of inhibition against the test organisms (Collins and Lyne, 1987). Wells injected with methanol and hexane served as negative controls.

\section{Results and Discussion}

\subsection{Fatty acids, vitamins and sterol contents in the} seeds of S. hortensis and M. spicata subsp. spicata

Essential fatty acids, are called polyunsaturated fatty acids, can not be produced by body and they must be taken from dietary sources (Singh, 2005). The intake of polyunsaturated fatty acids have been shown to reduce the risk of coronary artery, other cardiovascular and some chronic diseases (Campos et al., 2008; Rajaram, 2014). The Lamiaceae is characterized by high percentage of unsaturated fatty acids (Azcan et al., 2004). Similarly, present study demonstrated that $S$. hortensis and M. spicata subsp. spicata from Lamiaceae have high polyunsaturated fatty acids.

The fatty acid compositions of $S$. hortensis and M. spicata subsp. spicata are given Table 1. It has been showed that palmitic acid $(\mathrm{C} 16: 0 ; 3.61 \pm 0.32 \%)$, stearic acid (C18:0; $1.52 \pm 0.22 \%)$, oleic acid (C18:1 n9; $7.13 \pm 0.49 \%)$, linoleic acid (C18:2 n6; $15.19 \pm 0.51 \%)$, $\alpha$-linolenic acid (C18:3 n3; $66.24 \pm 1.42 \%), \gamma$-linolenic acid (C18:3 n6; $1.04 \pm 0.14 \%)$ and stearidonic acid (C18:4; $4.63 \pm 0.39 \%)$ are the major fatty acids of S. hortensis.

Table 1. Fatty acid compositions in seeds of S. hortensis L. and M. spicata L. subsp. spicata.

\begin{tabular}{ccc}
\hline Fatty acids & S. hortensis & M. spicata \\
\hline C16:0 & $3.61 \pm 0.32$ & $5.11 \pm 0.41$ \\
C18:0 & $1.52 \pm 0.22$ & $1.92 \pm 0.21$ \\
C20:0 & $0.12 \pm 0.07$ & $0.21 \pm 0.07$ \\
ESFA & $\mathbf{5 . 2 5} \pm \mathbf{0 . 2}$ & $\mathbf{7 . 2 4} \pm \mathbf{0 . 2 3}$ \\
C16:1 n9 & $0.39 \pm 0.01$ & $0.52 \pm 0.14$ \\
C18:1 n9 & $7.13 \pm 0.49$ & $8.19 \pm 0.42$ \\
C20:1 n9 & $0.11 \pm 0.02$ & $0.21 \pm 0.06$ \\
C24:1 & $0.12 \pm 0.04$ & - \\
EMUFA & $\mathbf{7 . 7 5} \pm \mathbf{0 . 1 4}$ & $\mathbf{8 . 9 2} \pm \mathbf{0 . 2}$ \\
C18:2 n6 & $15.19 \pm 0.51$ & $31.14 \pm 0.98$ \\
C18:3 n3 & $66.24 \pm 1.42$ & $48.17 \pm 1.01$ \\
C18:3 n6 & $1.04 \pm 0.14$ & $2.07 \pm 0.22$ \\
C18:4 & $4.63 \pm 0.39$ & $3.02 \pm 0.18$ \\
EPUFA & $\mathbf{8 7 . 1} \pm \mathbf{0 . 6 1}$ & $\mathbf{8 4 . 4} \pm \mathbf{0 . 5 9}$ \\
\hline
\end{tabular}


Gören et al. (2003) determined that seeds of Satureja thymbra riched in oleic acid (43.9\%), linolenic acid (30.2\%), stearic acid (14.1\%) and palmitic acid (11.4\%) contents. They also demonstrated that Satureja cuneifolia has palmitic acid (34.6\%) and oleic acid (10.1\%) contents (Gören et al., 2003). On the other hand, Tepe and Cilkiz (2016) indicated that Satureja has palmitic acid, oleic acid, linoleic acid and linolenic acids as fatty acids. Also, present study showed that the main fatty acids of $M$. spicata are palmitic acid (C16:0; $5.11 \pm 0.41 \%)$, stearic acid (C18:0; $1.92 \pm 0.21 \%)$, oleic acid (C18:1 n9; $8.19 \pm 0.42 \%)$, linoleic acid (C18:2 n6; $31.14 \pm 0.98 \%), \alpha$-linolenic acid (C18:3 n3; $48.17 \pm 1.01 \%), \gamma$-linolenic acid (C18:3 n6; $2.07 \pm 0.22 \%)$ and stearidonic acid (C18:4; $3.02 \pm 0.18 \%)$. Rao and Lakshminarayana (1988) determined that the major fatty acids of Mentha arvensis are linolenic acid (C18:3), palmitic acid (C16:0) and linoleic acid (C18:2). Also, the studies showed that Mentha species (including M. spicata) contained high $\alpha$-linolenic acid (Pereira et al., 2001). On the contrary, the results of El-Sayeda et al. (2014) conflict with present study. They indicated that Mentha has palmitic acid (C16:0; 45.27\%), stearic acid (C18:0; 5.67\%), oleic acid (C18:1 n9; 5.3\%), linoleic acid (C18:2 n6; 7.86\%) and linolenic acid (C18:3 n6;19.26\%) contents (El-Sayeda et al., 2014). Similarly, Tulukcu (2011) determined that Mentha has high saturated fatty acids such as palmitic acid (C16:0) is $24.5 \%$ and stearic acid (C18:0) is $20.01 \%$. And also, Tulukcu (2011) found that oleic acid (C18:1) and linoleic acid (C18:2) are lowest (4.80\%, $7.30 \%$, respectively) while linolenic acid (C18:3) content is high (29.5\%). Furthermore, Conforti et al. (2011) found that linoleic acid and linolenic acid contents of Mentha spicata are trace amounts.

Phytosterols are known as total and LDL cholesterol reducing effect in patients with metabolic syndrome and diabetes (Fassbender et al., 2008; Sialvera et al., 2012; Demonty et al., 2013). Also, they might also protect against certain types of cancer such as colon, breast and prostate (Tasan et al., 2006). Sitosterol, campesterol and stigmasterol are the most common plant sterols in nature (Jong et al., 2003). It has been demonstrated that ergosterol $(263.1 \pm 2.14 \mu \mathrm{g} / \mathrm{g})$, stigmasterol $(39.07 \pm 0.91 \mu \mathrm{g} / \mathrm{g})$ and beta-sitosterol $(14.64 \pm 0.49 \mu \mathrm{g} / \mathrm{g})$ have been found in M. spicata subsp. spicata, while ergosterol $(69.41 \pm 1.75 \mu \mathrm{g} / \mathrm{g})$ and beta-sitosterol $(19.81 \pm 1.14 \mu \mathrm{g} / \mathrm{g})$ have been found in S. hortensis in the present study (Table 2). It has been found that the sterol contents of M. spicata subsp. spicata are higher than those of $S$. hortensis in the present study. The study done by El-Sayeda et al. (2014) found that Mentha has $\beta$-sitosterol (5.6\%) and stigmasterol (1.9\%) contents whilst Conforti et al. (2008) found that $\gamma$-sitosterol is the predominant sterol in the Mentha investigated.

The fat soluble-vitamins (ADEK) have various biological actions related to protection the human health and their absence cause to important problems such as cancer, diabetes, osteoroporosis and immune system defects (Blanco et al., 2000; Mazzini et al., 2006; Albahrani and Greaves, 2016). Vitamin E are serious compounds in scavenging membrane phospholipids against free radicals attacts (Chai et al., 2012; Rizvi et al., 2014; Borel and Desmarchelier, 2016). Also, vitamin $\mathrm{D}$ are act as absorption of calcium and phosphate from intestinal and in the storage of these minerals in the bone (Capote et al., 2007; Chai et al., 2012). In addition to the protective role of vitamin $\mathrm{A}$ in the eye it has also effective in the carbohydrate, lipids and protein metabolism whilst vitamin $\mathrm{K}$ has role in the blood coagulation (Chen et al., 2011; Albahrani and Greaves, 2016). Some vitamins such as vitamin $\mathrm{A}$ and D play role as hormones and operate their role at intracellular receptor sites (Ravinaskar et al., $2015)$. The present study showed that $S$. hortensis contains $\alpha$-tocopherol (35.18 $\pm 0.92 \mu \mathrm{g} / \mathrm{g})$, retinol $(6.33 \pm 0.51 \mu \mathrm{g} / \mathrm{g})$, $\mathrm{K} 2(1.61 \pm 0.21 \mu \mathrm{g} / \mathrm{g}) \mathrm{D} 3(86.87 \pm 1.51 \mu \mathrm{g} / \mathrm{g})$, and D2 vitamins $(0.25 \pm 0.07 \mu \mathrm{g} / \mathrm{g})$ whilst $M$. spicata subsp. spicata contains r-tocopherol $(31.51 \pm 1.01 \mu \mathrm{g} / \mathrm{g})$, D3 $(162.23 \pm 2.41 \mu \mathrm{g} / \mathrm{g}), \alpha$-tocopherol $(0.84 \pm 0.17 \mu \mathrm{g} / \mathrm{g})$ and retinol-acetate $(0.21 \pm 0.07 \mu \mathrm{g} / \mathrm{g})$ as lipide-soluble vitamins (Table 2). Chanwitheesuk et al. (2005) found that two Mentha species contained 0.0054-0.0294 mg\% vitamin E content.

\subsection{Flavonoid contents and radical scavenging capacities in the seeds of $S$. hortensis and M. spicata subsp. spicata}

Phenolics, are one of main group herbal compounds, have potent to high antioxidant capacity against free radical damage (Benabdallah et al., 2016). It has been indicated that species from Lamiaceae have strong antioxidant capacity mostly due to phenolic compounds (Hossain et al., 2010). The variety of phenolics reduce cancer growth by capturing cancer cells in the certain phases of the cell cycle, heart disease and diabetes (Berdowska et al., 2013;

Table 2. Lipide-soluble vitamin and sterol contents in seeds of S. hortensis L. and M. spicata L. subsp. spicata.

\begin{tabular}{|c|c|c|c|c|c|c|c|c|c|c|c|}
\hline \multicolumn{9}{|c|}{ Lipide-soluble vitamins $(\mu \mathrm{g} / \mathrm{g})$} & \multicolumn{3}{|c|}{ Sterols $(\mu \mathrm{g} / \mathrm{g})$} \\
\hline$\underset{\tilde{x}}{\pi}$ & $\underline{1}$ & $\underline{z}$ & 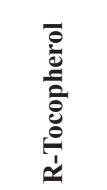 & $\tilde{\Omega}$ & $\tilde{\theta}$ & $\begin{array}{l}\overline{0} \\
\frac{0}{0} \\
\frac{0}{0} \\
\frac{0}{0} \\
\frac{0}{2}\end{array}$ & 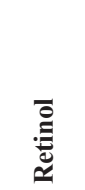 & 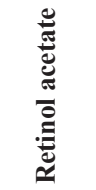 & 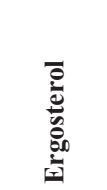 & 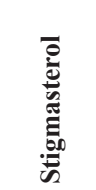 & 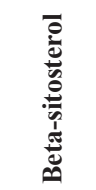 \\
\hline S. hortensis & $\begin{array}{c}1.61 \pm \\
0.21\end{array}$ & - & - & $\begin{array}{c}0.25 \pm \\
0.07\end{array}$ & $\begin{array}{c}86.87 \pm \\
1.51\end{array}$ & $\begin{array}{c}35.18 \pm \\
0.92\end{array}$ & $\begin{array}{c}6.33 \pm \\
0.51\end{array}$ & - & $\begin{array}{c}69.41 \pm \\
1.75\end{array}$ & - & $\begin{array}{c}19.81 \pm \\
1.14\end{array}$ \\
\hline M. spicata & - & - & $\begin{array}{c}31.51 \pm \\
1.01\end{array}$ & - & $\begin{array}{l}162.23 \\
\pm 2.41\end{array}$ & $\begin{array}{c}0.84 \pm \\
0.17\end{array}$ & - & $\begin{array}{c}0.21 \pm \\
0.07\end{array}$ & $\begin{array}{c}263.1 \pm \\
2.14\end{array}$ & $\begin{array}{c}39.07 \pm \\
0.91\end{array}$ & $\begin{array}{c}14.64 \pm \\
0.49\end{array}$ \\
\hline
\end{tabular}


Shahidi and Ambigaipalan, 2015). Flavonoids are most abundant compounds of phenolics in the plants and contained 6000 chemicals (Gomaa et al., 2015). Total nine flavonoids (rutin, myricetin, morin, quercetin, kaempferol, catechin, naringin, naringenin, resveratrol) are studied in this study (Table 3 ). It has been found that S. hortensis contained naringenin $(612.57 \pm 2.57 \mu \mathrm{g} / \mathrm{g})$, morin $(86.97 \pm 1.12 \mu \mathrm{g} / \mathrm{g})$, quercetin $(22.87 \pm 0.75 \mu \mathrm{g} / \mathrm{g})$, and kaempferol $(20.11 \pm 0.94 \mu \mathrm{g} / \mathrm{g})$. However, myricetin, catechin and naringin aren't identified in the seeds of $S$. hortensis. Literatures showed that Satureja has natural phenolic compounds (Zheng and Wang, 2001; Zeljkovic et al., 2015). It has been determined that Satureja has luteolin and naringenin contents studies done by different researchers (Skoula et al., 2005; Kosar et al., 2005). Oke et al. (2009) suggested that the amounts of total phenols found in the Satureja methanolic extract are very high. Also, Tepe and Cilkiz (2016) reviewed that Satureja has catechin, naringin, naringenin, kaepmherol, apigenin, luteolin, rutin and myricetin whilst Boroja et al. (2018) demonstrated that Satureja hortensis contains apigenin, kaempherol, luteolin, naringin, naringenin and quercetin. On the other hand, naringenin $(135.91 \pm 1.91 \mu \mathrm{g} / \mathrm{g})$, naringin $(61.23 \pm 2.15 \mu \mathrm{g} / \mathrm{g})$, quercetin $(47.51 \pm 1.17 \mu \mathrm{g} / \mathrm{g})$ have been identified as the major flavonoids in the seeds of M. spicata subsp. spicata. But myricetin and catechin constituents are not detected in the seeds of M. spicata subsp. spicata. Bimakr et al. (2011) found that Mentha contains catechin, epicatechin, rutin, myricetin, luteolin, apigenin and naringenin. Also, Farzaei et al. (2017) showed that Mentha has luteolin and apigenin contents. However, Tang et al. (2016) determined apigenin and naringenin as minor compounds. Furthermore, different studies suggested that Mentha has very high total phenolic content and the ability to scavenge the free radical DPPH (Capecka et al., 2005; Stringaro et al., 2018).

The results related to the radical-scavenging potential of $S$. hortensis and $M$. spicata subsp. spicata are summarized in Table 3. It has been found that 25 and $50 \mu \mathrm{L}$ methanolic extracts of $S$. hortensis $(89.62 \pm 1.17 \%, 85.24 \pm 1.24 \%$, respectively) exhibited higher radical scavenging activity than those of M. spicata subsp. spicata $(66.85 \pm 1.01 \%$, $89.91 \pm 2.12 \%$, respectively); this might be due to the high flavonoid concentration of $S$. hortensis. Several studies indicated that methanol extracts of Satureja species exhibited high antioxidant activity (Eminagaoglu et al., 2007; Oke et al., 2009; Alonso-Carrillo et al., 2017). Dorman and Hiltunen (2004) suggested that the crude and ethyle acetate extracts of Satureja are capable of scavenging reactive free radical species. It has been suggested that the extracts of $S$. hortensis may be able to defend sensitive constituents such as amino acids, DNA, lipoproteins, polyunsaturated fatty acids, sugars and proteins from oxidative stress (Dorman and Hiltunen, 2004; Zahedifar and Najafian, 2015). Besides, different studies demonstrated that Mentha species represent strong antioxidant activity and high phenolic constituent (Tawaha et al., 2007; Benabdallah et al., 2016; Tang et al., 2016). Unver et al. (2009) and Conforti et al. (2008) indicated that Mentha has high free radical scavenging capacity. Also, Sytar et al. (2018) found that Mentha spicata subsp. spicata has phenolic content and high antioxidant capacity. Furthermore, Motamed and Naghibi (2010) indicated that Mentha (93.68\%) and Satureja species (93.39\%) have the highest DPPH radical scavenging activity. These results suggested that methanol extracts of $S$. hortensis and M. spicata subsp. spicata have significant free radical scavenging activity.

\subsection{Antimicrobial activities of lipid soluble vitamins, flavonoids and fatty acids in the seeds of S. hortensis and M. spicata subsp. spicata}

The antimicrobial capacities of seed extracts have many practices comprising pharmaceuticals, food protection, natural therapies and alternative medicine (Reynolds, 1996; Lis-Balchin and Deans, 1997; Kelen and Tepe, 2008). The antimicrobial activities of vitamins, flavonoids and fatty acids of the studied species, negative control group and standart antibiotics have been showed in Table 4. It has been found that the extracts of vitamins and flavonoids in seeds have antibacterial and antifungal activity against the microorganisms tested but it seems that the antimicrobial activities of fatty acids extracts of seeds are lower than flavonoids and vitamins extracts (Table 4).

Table 4 shows that the vitamin extracts of S. hortensis have the maximum antimicrobial activity against all of the tested microorganisms: E. coli $(12.1 \pm 0.1 \mathrm{~mm})$, K. pneumoniae $(23.2 \pm 0.3 \mathrm{~mm}), S$. aureus $(30.7 \pm 0.1 \mathrm{~mm})$, B. megaterium (19.1 $\pm 0.2 \mathrm{~mm})$, C. albicans $(22.4 \pm 0.3 \mathrm{~mm})$ C. glabrata $(17.5 \pm 0.2 \mathrm{~mm})$, Epidermophyton $\mathrm{sp} .(23.4 \pm 0.3 \mathrm{~mm})$, Trichophyton sp. $(21.1 \pm 0.3 \mathrm{~mm})$. Similarly, the flavonoid extracts of $S$. hortensis showed the maximum antimicrobial activity against the tested microorganisms, listed from high to low as: E. coli (35.1 $\pm 0.1 \mathrm{~mm})$, S. aureus $(34.4 \pm 0.3 \mathrm{~mm})$, $K$. pneumoniae $(25.1 \pm 0.2 \mathrm{~mm})$, C. albicans $(23.1 \pm 0.2 \mathrm{~mm})$, B. megaterium $(21.4 \pm 0.4 \mathrm{~mm})$, Epidermophyton $\mathrm{sp}$. $(21.3 \pm 0.4 \mathrm{~mm})$, Trichophyton $\mathrm{sp} .(16.2 \pm 0.2 \mathrm{~mm})$ and C. glabrata $(15.3 \pm 0.3 \mathrm{~mm})$. The fatty acids in seeds of $S$. hortensis did not show any antifungal activity against C. albicans, C. glabrata, Epidermophyton sp. and Trichophyton sp. However, the fatty acids in seeds

Table 3. Flavonoid and radical scavenging capacities in seeds of S. hortensis L. and M. spicata L. subsp. spicata.

\begin{tabular}{|c|c|c|c|c|c|c|c|c|c|}
\hline \multicolumn{8}{|c|}{ Flavonoids $(\mu \mathrm{g} / \mathrm{g})$} & \multicolumn{2}{|c|}{ inhibiton $\%$} \\
\hline & Myricetin & Morin & Quercetin & Kaempferol & Catechin & Naringin & Naringenin & $25 \mu \mathrm{L}$ & $50 \mu \mathrm{L}$ \\
\hline S. hortensis & - & $\begin{array}{c}86.97 \pm \\
1.12\end{array}$ & $\begin{array}{c}22.87 \pm \\
0.75\end{array}$ & $20.11 \pm 0.94$ & - & - & $\begin{array}{c}612.57 \pm \\
2.57\end{array}$ & $\begin{array}{c}89.63 \pm \\
1.17\end{array}$ & $\begin{array}{c}85.24 \pm \\
1.24\end{array}$ \\
\hline M. spicata & - & $\begin{array}{c}0.13 \pm \\
0.06\end{array}$ & $\begin{array}{c}47.51 \pm \\
1.17\end{array}$ & $0.36 \pm 0.04$ & - & $\begin{array}{c}61.23 \pm \\
2.15\end{array}$ & $\begin{array}{c}135.91 \pm \\
1.91\end{array}$ & $\begin{array}{c}66.85 \pm \\
1.01\end{array}$ & $\begin{array}{c}89.91 \pm \\
2.12\end{array}$ \\
\hline
\end{tabular}


Table 4. Antimicrobial activities of seed extracts containing vitamins, flavanoids and fatty acids.

\begin{tabular}{|c|c|c|c|c|c|c|c|c|c|}
\hline \multirow{3}{*}{ Microorganisms } & \multicolumn{9}{|c|}{ Inhibition zone (mm) } \\
\hline & \multicolumn{2}{|c|}{ Vitamins } & \multicolumn{2}{|c|}{ Flavonoids } & \multicolumn{2}{|c|}{ Fatty acids } & \multicolumn{3}{|c|}{ Control } \\
\hline & S.h. & M. s. & S.h. & M. s. & S.h. & M. s. & Methanol & Hexan & Standart \\
\hline E. coli & $\begin{array}{c}12.1 \pm \\
0.1\end{array}$ & $\begin{array}{c}15.1 \pm \\
0.2\end{array}$ & $\begin{array}{c}35.1 \pm \\
0.1\end{array}$ & $\begin{array}{c}23.1 \pm \\
0.2\end{array}$ & $\begin{array}{c}11.2 \pm \\
0.1\end{array}$ & - & - & $\begin{array}{c}15.3 \pm \\
0.4\end{array}$ & $\begin{array}{l}10.1 \pm \\
0.2 * *\end{array}$ \\
\hline K.pneumoniae & $\begin{array}{c}23.2 \pm \\
0.3\end{array}$ & $\begin{array}{c}25.7 \pm \\
0.3\end{array}$ & $\begin{array}{c}25.1 \pm \\
0.1\end{array}$ & $\begin{array}{c}32.4 \pm \\
0.4\end{array}$ & $\begin{array}{c}8.2 \pm \\
0.4\end{array}$ & $\begin{array}{c}13.2 \pm \\
0.1\end{array}$ & - & $\begin{array}{c}14.2 \pm \\
0.4\end{array}$ & $\begin{array}{l}9.4 \pm \\
0.1 * *\end{array}$ \\
\hline S. aureus & $\begin{array}{c}30.7 \pm \\
0.1\end{array}$ & $\begin{array}{c}21.2 \pm \\
0.5\end{array}$ & $\begin{array}{c}34.4 \pm \\
0.3\end{array}$ & $\begin{array}{c}13.3 \pm \\
0.4\end{array}$ & $\begin{array}{c}13.1 \pm \\
0.3\end{array}$ & - & - & $\begin{array}{c}13.2 \pm \\
0.2\end{array}$ & $\begin{array}{l}13.2 \pm \\
0.2 * *\end{array}$ \\
\hline B. megaterium & $\begin{array}{c}19.1 \pm \\
0.2\end{array}$ & $\begin{array}{c}25.6 \pm \\
0.4\end{array}$ & $\begin{array}{c}21.4 \pm \\
0.4\end{array}$ & $\begin{array}{c}35.7 \pm \\
0.5\end{array}$ & $\begin{array}{c}8.3 \pm \\
0.2\end{array}$ & $\begin{array}{c}11.4 \pm \\
0.1\end{array}$ & - & $\begin{array}{c}12.1 \pm \\
0.1\end{array}$ & $\begin{array}{l}9.3 \pm \\
0.2 * *\end{array}$ \\
\hline C. albicans & $\begin{array}{c}22.4 \pm \\
0.3\end{array}$ & $\begin{array}{c}24.1 \pm \\
0.3\end{array}$ & $\begin{array}{c}23.1 \pm \\
0.2\end{array}$ & $\begin{array}{c}17.6 \pm \\
0.6\end{array}$ & - & - & - & $\begin{array}{c}17.1 \pm \\
0.1\end{array}$ & $\begin{array}{c}18.1 \pm \\
0.3^{*}\end{array}$ \\
\hline C. glabrata & $\begin{array}{c}17.5 \pm \\
0.2\end{array}$ & $\begin{array}{c}18.4 \pm \\
0.3\end{array}$ & $\begin{array}{c}15.3 \pm \\
0.3\end{array}$ & $\begin{array}{c}11.1 \pm \\
0.3\end{array}$ & - & - & - & $\begin{array}{c}11.4 \pm \\
0.7\end{array}$ & $\begin{array}{c}12.3 \pm \\
0.1^{*}\end{array}$ \\
\hline Trichophyton sp. & $\begin{array}{c}23.4 \pm \\
0.3\end{array}$ & $\begin{array}{c}24.3 \pm \\
0.2\end{array}$ & $\begin{array}{c}16.2 \pm \\
0.2\end{array}$ & - & - & - & - & $\begin{array}{c}17.3 \pm \\
0.6\end{array}$ & NT \\
\hline Epidermophyton sp. & $\begin{array}{c}21.1 \pm \\
0.3\end{array}$ & $\begin{array}{c}18.1 \pm \\
0.1\end{array}$ & $\begin{array}{c}21.3 \pm \\
0.4\end{array}$ & $\begin{array}{c}11.5 \pm \\
0.2\end{array}$ & - & - & - & $\begin{array}{c}9.1 \pm \\
0.1\end{array}$ & NT \\
\hline
\end{tabular}

S.h. $=$ S. hortensis L., M.s. = M. spicata L. subsp. spicata. Standart: *Nystatin (30 $\mu \mathrm{g} / \mathrm{disc}),{ }^{*}$ Streptomysin sulphate $(10 \mu \mathrm{g} / \mathrm{disc})$; Control: methanol and hexan $(10 \mu \mathrm{L})$; NT = not tested.

of Satureja hortensis showed antibacterial activity against E. coli $(11.2 \pm 0.1 \mathrm{~mm})$, K. pneumoniae $(8.2 \pm 0.4 \mathrm{~mm})$, $S$. aureus $(13.1 \pm 0.3 \mathrm{~mm})$, and $B$. megaterium $(8.3 \pm 0.2 \mathrm{~mm})$ (Table 4). Several studies revealed that Satureja species showed major activity against the gram positive and gram microorganisms, fungi and yeast (Dikbas et al., 2009; Choulitoudi et al., 2016; Tepe and Cilkiz, 2016; Valdivieso-Ugarte et al., 2019; Vitanza et al., 2019). On the other hand, the results obtained from study of Sahin et al. (2003) showed that hexane extract of S. hortensis don't have antifungal, but they observed antibacterial activity against four strains of three Bacillus species.

Furthermore, the vitamin extracts in the seeds of M. spicata subsp. spicata have strongly antimicrobial effect over some tested microrganisms; $K$. pneumoniae (25 mm), B. megaterium (25 mm), C. albicans (24 mm), Epidermophyton sp. (24 mm), S. aureus $(21 \mathrm{~mm})$, C. glabrata (18 mm), Trichophyton $\mathrm{sp} .(18 \mathrm{~mm})$ and E. coli $(15 \mathrm{~mm})$ (Table 4). Also, the extracts of flavonoids in the seeds of M. spicata have antimicrobial activity on E. coli, $K$. pneumoniae, $S$. aureus, B. megaterium, C. albicans, C. glabrata and Trichophyton sp. (13 mm, $23 \mathrm{~mm}, 13 \mathrm{~mm}$, $35 \mathrm{~mm}, 17 \mathrm{~mm}, 11 \mathrm{~mm}$ and $19 \mathrm{~mm}$ zone of inhibition respectivelly) while it has not antimicrobial activity on Epidermophyton sp. However; the fatty acids in the seeds of $M$. spicata subsp. spicata exhibited antimicrobial effect over K. pneumoniae (13 mm) and B. megaterium (11 mm), where as those have not antimicrobial effect on the other tested microrganisms: E. coli, S. aureus, C. albicans, C. glabrata, Epidermophyton sp. and Trichophyton sp. It has been reported that chemical compositions of Mentha species have antifungal properties against human pathogens (Malassezia furfur, Trichophyton rubrum, and
Trichosporon beigelii) and inhibited efficiently antimicrobials (Yadegarinia et al., 2006; Mahboubi and Haghi, 2008; Scherer et al., 2013; Biswas et al., 2014; Singh et al., 2015; Alexa et al., 2018). On the contrary, Gulluce et al. (2007) reported the methanol extract from aerial parts of Mentha showed no antimicrobial activities.

\section{Conclusions}

The present study found that $\alpha$-linolenic acid (C18:3 n3) is the major polyunsaturated fatty acid of $S$. hortensis $(87.1 \pm 0.61 \%)$ and $M$. spicata subsp. spicata $(84.4 \pm 0.59 \%)$. It has been showed that the saturated fatty acids of $S$. hortensis and M. spicata subsp. spicata low. Also, ergosterol has been found to be a major sterol in the studied taxa. However, it has been found that $S$. hortensis and M. spicata subsp. spicata have low lipide-soluble vitamin content. On the other hand, naringenin and quercetin have been identified as the predominant flavonoids in S. hortensis and M. spicata subsp. spicata. Furthermore, present results suggested that methanol extracts of $S$. hortensis and M. spicata subsp. spicata display significant free radical scavenging activity. In addition, the present results indicated that $S$. hortensis and M. spicata subsp. spicata showed major activity against gram-positive and gram-negative microorganisms, fungi and yeast.

\section{References}

ABD EL TAWAB, A.M., SHAHIN, N.N. and ABDELMOHSEN, M.M., 2014. Protective effect of Satureja montana extract on cyclophosphamide-induced testicular injury in rats. ChemicoBiological Interactions, vol. 224, pp. 196-205. http://dx.doi. org/10.1016/j.cbi.2014.11.001. PMid:25446862. 
AKSIT, H., DEMIRTAS, I., TELCI, I. and TARIMCILAR, G., 2013. Chemical diversity in essential oil composition of Mentha longifolia (L.) Hudson subsp. typhoides (Briq.) Harley var. typhoides from Turkey. The Journal of Essential Oil Research, vol. 25, no. 5, pp. 430-437. http://dx.doi.org/10.1080/10412905.2013.829005.

ALBAHRANI,A.A. and GREAVES, R.F., 2016. Fat-soluble vitamins: clinical indications and current challenges for chromatographic measurement. The Clinical Biochemist: Reviews, vol. 37, no. 1, pp. 27-47. PMid:27057076.

ALEXA, E., DANCIU, C., COCAN, I., NEGREA, M., MORAR, A., OBISTIOIU, D., DOGARU, D.I., BERBECEA, A. and RADULOV, I., 2018. Chemical composition and antimicrobial potential of Satureja hortensis L. in fresh cow cheese. Journal of Food Quality, vol. 2018, pp. 1-10. http://dx.doi.org/10.1155/2018/8424035.

ALONSO-CARRILLO, N., AGUILAR-SANTAMARIA, L.A., VERNON-CARTER, E.J., JIMENEZ-ALVARADO, R., CRUZSOSA, F. and ROMAN-GUERRERO, A., 2017. Extraction of phenolic compounds from Satureja macrostema using microwaveultrasound assisted and reflux methods and evaluation of their antioxidant activity and cytotoxicity. Industrial Crops and Products, vol. 103, pp. 213-221. http://dx.doi.org/10.1016/j. indcrop.2017.04.002.

AZCAN, N., ERTAN, A., DEMIRCI, B. and BASER, K.H.C., 2004. fatty acid composition of seed oils of twelve Salvia species growing in Turkey. Chemistry of Natural Compounds, vol. 40, no. 3, pp. 218-221. http://dx.doi.org/10.1023/B:CONC.0000039127.56323.3e.

BENABDALLAH, A., BOUMENDJEL, M., AISSI, O., RAHMOUNE, C., BOUSSAID, M. and MESSAOUD, C., 2018. Chemical composition, antioxidant activity and acetylcholin esterase inhibitory of wild Mentha species from northeastern Algeria. South African Journal of Botany, vol. 116, pp. 131-139. http://dx.doi.org/10.1016/j.sajb.2018.03.002.

BENABDALLAH, A., RAHMOUNE, C., BOUMENDJEL, M., AISSI, O. and MESSAOUD, C., 2016. Total phenolic content and antioxidant activity of six wild Mentha species (Lamiaceae) from northeast of Algeria. Asian Pacific Journal of Tropical Biomedicine, vol. 6, no. 9, pp. 760-766. http://dx.doi.org/10.1016/j. apjtb.2016.06.016.

BERDOWSKA, I., ZIELIŃSKI, B., FECKA, I., KULBACKA, J., SACZKO, J. and GAMIAN, A., 2013. Cytotoxic impact of phenolics from Lamiaceae species on human breast cancer cells. Food Chemistry, vol. 141, no. 2, pp. 1313-1321. http://dx.doi. org/10.1016/j.foodchem.2013.03.090. PMid:23790919.

BIMAKR, M., RAHMAN, R.A., TAIP, F.S., GANJLOO, A., SALLEH, L.M., SELAMAT, J., HAMID, A. and ZAIDUL, I.S.M., 2011. Comparison of different extraction methods for the extraction of major bioactive flavonoid compounds from spearmint (Mentha spicata L.) leaves. Food and Bioproducts Processing, vol. 89, no. 1, pp. 67-72. http://dx.doi.org/10.1016/j. fbp.2010.03.002.

BISWAS, N.N., SAHA, S. and ALI, M.K., 2014. Antioxidant, antimicrobial, cytotoxic and analgesic activities of ethanolic extract of Mentha arvensis L. Asian Pacific Journal of Tropical Biomedicine, vol. 4, no. 10, pp. 792-797. http://dx.doi.org/10.12980/ APJTB.4.2014C1298.

BLANCO, D., FERNANDEZ, M.P. and GUTIERREZ, M.D., 2000. Simultaneous determination of fat-soluble vitamins and provitamins in dairy products by liquid chromatography with a narrow-bore column. Analyst, vol. 125, no. 3, pp. 427-431. http:// dx.doi.org/10.1039/a909027d. PMid:10829342.
BOREL, P. and DESMARCHELIER, C., 2016. Genetic variations involved in vitamin E status. International Journal of Molecular Sciences, vol. 17, no. 12, pp. 1-11. http://dx.doi.org/10.3390/ ijms 17122094. PMid:27983595.

BOROJA, T., KATANIC, J., ROSIC, G., SELAKOVIĆ, D., JOKSIMOVIĆ, J., MIŠIĆ, D., STANKOVIĆ, V., JOVIČIĆ, N. and MIHAILOVIĆ, V., 2018. Summer savory (Satureja hortensis L.) extract: phytochemical profile and modulation of cisplatininduced liver, renal and testicular toxicity. Food and Chemical Toxicology, vol. 118, pp. 252-263. http://dx.doi.org/10.1016/j. fct.2018.05.001. PMid:29746935.

CAMPOS, H., BAYLIN, A. and WILLETT, W.C., 2008. $\alpha$-linolenic acid and risk of nonfatal acute myocardial infarction. Circulation, vol. 118, no. 4, pp. 339-345. http://dx.doi.org/10.1161/ CIRCULATIONAHA.107.762419. PMid:18606916.

CAPECKA, E., MARECZEK, A. and LEJA, M., 2005. Antioxidant activity of fresh and dry herbs of some Lamiaceae species. Food Chemistry, vol. 93, no. 2, pp. 223-226. http://dx.doi.org/10.1016/j. foodchem.2004.09.020

CAPOTE, F.P., JIMENEZ, J.M., GRANADOS, M. and CASTRO, M.D.L., 2007. Identification and determination of fat-soluble vitamins and metabolites in human serum by liquid chromatography/triple quadrupole mass spectrometry with multiple reaction monitoring. Rapid Communications in Mass Spectrometry, vol. 21, no. 11, pp. 1745-1754. http://dx.doi.org/10.1002/rcm.3014. PMid:17486676.

CHAI, W., BOSTICK, R.M., AHEARN, T.U., FRANKE, A.A., CUSTER, L.J. and COONEY, R.V., 2012. Effects of vitamin D3 and calcium supplementation on serum levels of tocopherols, retinol, and specific vitamin D metabolites. Nutrition and Cancer, vol. 64, no. 1, pp. 57-64. http://dx.doi.org/10.1080/01635581.20 12.630552. PMid:22149065.

CHANWITHEESUK, A., TEERAWUTGULRAG, A. and RAKARIYATHAM, N., 2005. Screening antioxidant activity and antioxidant compounds of some edible plants of Thailand. Food Chemistry, vol. 92, no. 3, pp. 491-497. http://dx.doi.org/10.1016/j. foodchem.2004.07.035

CHEN, L., LIU, Z., KANG, X., ZHOU, X., ZHENG, S. and GU, Z., 2011. Determination of fat-soluble vitamins in food and pharmaceutical supplements using packed-fiber solid phase extraction (PFSPE) for sample preconcentration/clean-up. Procedia Environmental Sciences, vol. 8, pp. 588-595. http:// dx.doi.org/10.1016/j.proenv.2011.10.091.

CHOULITOUDI, E., BRAVOU, K., BIMPILAS, A., TSIRONI, T., TSIMOGIANNIS, D., TAOUKIS, P. and OREOPOULOU, V., 2016. Antimicrobial and antioxidant activity of Satureja thymbra in gilthead seabream fillets edible coating. Food and Bioproducts Processing, vol. 100, pp. 570-577. http://dx.doi.org/10.1016/j. fbp.2016.06.013.

CHRISTIE, W.W., 1990. Gas chromatography and lipids. Glaskow: The Oily Press, pp. 573-577.

COLLINS, C.M. and LYNE, P.M., 1987. Microbiological methods. London: Buttermorths \& Co. (Publishers) Ltd., 450 p.

CONFORTI, F., MARRELLI, M., CARMELA, C., MENICHINI, F., VALENTINA, P., UZUNOV, D., STATTI, G.A., DUEZ, P. and MENICHINI, F., 2011. Bioactive phytonutrients (omega fatty acids, tocopherols, polyphenols), in vitro inhibition of nitric oxide production and free radical scavenging activity of non-cultivated Mediterranean vegetables. Food Chemistry, vol. 129, no. 4, pp. 1413-1419. http://dx.doi.org/10.1016/j.foodchem.2011.05.085. 
CONFORTI, F., SOSA, S., MARRELLI, M., MENICHINI, F., STATTI, G.A., UZUNOV, D., TUBARO, A., MENICHINI, F. and LOGGIA, R.D., 2008. In vivo anti-inflammatory and in vitro antioxidant activities of Mediterranean dietary plants. Journal of Ethnopharmacology, vol. 116, no. 1, pp. 144-151. http://dx.doi. org/10.1016/j.jep.2007.11.015. PMid:18164564.

DAVIS, P.H., 1982. Flora of Turkey and the Aegean Islands. Edinburgh: Edinburgh University Press, vol. 7.

DEMONTY, I., RAS, R.T., VAN DER KNAAP, H.C.M., MEIJER, L., ZOCK, P.L., GELEIJNSE, J.M. and TRAUTWEIN, E.A., 2013. The effect of plant sterols on serum triglyceride concentrations is dependent on baseline concentrations: a pooled analysis of 12 randomised controlled trials. European Journal of Nutrition, vol. 52, no. 1, pp. 153-160. http://dx.doi.org/10.1007/s00394-0110297-x. PMid:22252793.

DIKBAS, N., KOTAN, R., DADASOGLU, F., KARAGOZ, K. and ÇAKMAKC, I.R., 2009. Correlation between major constituents and antibacterial activities of some plant essential oils against some pathogenic bacteria. Turkish Journal of Science \& Technology, vol. 4, no. 1, pp. 57-64.

DORMAN, H.J.D. and HILTUNEN, R., 2004. Fe (III) reductive and free radical-scavenging properties of summer savory (Satureja hortensis L.) extract and subfractions. Food Chemistry, vol. 88, no. 2, pp. 193-199. http://dx.doi.org/10.1016/j.foodchem.2003.12.039.

EL-SAYEDA, A.E.-K., HESHAM, I.E.-A., ZEINAB, A.K., SHAHIRA, M.E., MOHAMED, A.S. and AMANY, A.S., 2014. Chemical and biological study of Mentha suaveolens Ehrh. cultivated in Egypt. Journal of Medicinal Plants Research, vol. 8, no. 20, pp. 747-755. http://dx.doi.org/10.5897/JMPR2014.5324.

EMINAGAOGLU, O., TEPE, B., YUMRUTAS, O., AKPULAT, H.A., DAFERERA, D., POLISSIOU, M. and SOKMEN, A., 2007. The in vitro antioxidative properties of the essential oils and methanol extracts of Satureja spicigera (K. Koch) Boiss. and Satureja cuneifolia ten. Food Chemistry, vol. 100, no. 1, pp. 339-343. http://dx.doi.org/10.1016/j.foodchem.2005.09.054.

FARZAEI, M.H., BAHRAMSOLTANI, R., GHOBADI, A., FARZAEI, F. and NAJAFI, F., 2017. Pharmacological activity of Mentha longifolia and its phytoconstituents. Journal of Traditional Chinese Medicine, vol. 37, no. 5, pp. 710-720. http:// dx.doi.org/10.1016/S0254-6272(17)30327-8. PMid:32188234.

FASSBENDER, K., LUTJOHANN, D., DIK, M.G., BREMMER, M., KÖNIG, J., WALTER, S., LIU, Y., LETIÈMBRE, M., VON BERGMANN, K. and JONKER, C., 2008. Moderately elevated plant sterol levels are associated with reduced cardovascular risk-The LASA study. Atherosclerosis, vol. 196, no. 1, pp. 283288. http://dx.doi.org/10.1016/j.atherosclerosis.2006.10.032. PMid:17137582.

GIÃO, M.S., GONZÁLEZ-SANJOSÉ, M.L., RIVERO-PÉREZ, M.D., PEREIRA, C.I., PINTADO, M.E. and MALCATA, F.X., 2007. Infusions of Portuguese medicinal plants: dependence of final antioxidant capacity and phenol content on extraction features. Journal of the Science of Food and Agriculture, vol. 87, no. 14, pp. 2638-2647. http://dx.doi.org/10.1002/jsfa.3023. PMid:20836172.

GOMAA, N.H., HASSAN, M.O., FAHMY, G.M., GONZÁLEZ, L., HAMMOUDA, O. and ATTEYA, A.M., 2015. Flavonoid profiling and nodulation of some legumes in response to the allelopathic stress of Sonchus oleraceus L. Acta Botanica Brasílica, vol. 29, no. 4, pp. 553-560. http://dx.doi.org/10.1590/0102-33062015abb0153.
GÖREN, A.C., BILSEL, G., ALTUN, M., SATIL, F. and DIRMENCI, T., 2003. Fatty acid composition of seeds of Satureja thymbra and Satureja cuneifolia. Zeitschrift fur Naturforschung, vol. 58, no. 7-8, pp. 502-504. http://dx.doi.org/10.1515/znc-2003-7-810. PMid:12939035.

GULLUCE, M., SAHIN, F., SOKMEN, M., OZER, H., DAFERERA, D., SOKMEN, A., POLISSIOU, M., ADIGUZEL, A. and OZKAN, H., 2007. Antimicrobial and antioxidant properties of the essential oils and methanol extract from Mentha longifolia L. ssp. longifolia. Food Chemistry, vol. 103, no. 4, pp. 1449-1456. http://dx.doi. org/10.1016/j.foodchem.2006.10.061.

GÜLLÜCE, M., SOKMEN, M., DAFERERA, D., AĞAR, G., OZKAN, H., KARTAL, N., POLISSIOU, M., SÖKMEN, A. and SAHIN, F., 2003. In vitro antibacterial, antifungal, and antioxidant activities of the essential oil and methanol extracts of herbal parts and callus cultures of Satureja hortensis L. Journal of Agricultural and Food Chemistry, vol. 51, no. 14, pp. 3958-3965. http://dx.doi. org/10.1021/jf0340308. PMid:12822930.

HARA, A. and RADIN, N.S., 1978. Lipid extraction of tissues with a low-toxicity solvent. Analytical Biochemistry, vol. 90, no. 1, pp. 420-426. http://dx.doi.org/10.1016/0003-2697(78)900465. PMid:727482.

HOSSAIN, M.B., RAI, D.K., BRUNTON, N.P., MARTIN-DIANA, A.B. and BARRY-RYAN, C., 2010. Characterization of phenolic composition in Lamiaceae spices by LC-ESI-MS/MS. Journal of Agricultural and Food Chemistry, vol. 58, no. 19, pp. 1057610581. http://dx.doi.org/10.1021/jf102042g. PMid:20825192.

JAVANMARDI, J., STUSHNOFF, C., LOCKE, E. and VIVANCO, J.M., 2003. Antioxidant activity and total phenolic content of Iranian Ocimum accessions. Food Chemistry, vol. 83, no. 4, pp. 547-550. http://dx.doi.org/10.1016/S0308-8146(03)00151-1.

JONG, A., PLAT, J. and MENSINK, R.P., 2003. Metabolic effects of plant sterols and stanols. The Journal of Nutritional Biochemistry, vol. 14, no. 7, pp. 362-369. http://dx.doi.org/10.1016/ S0955-2863(03)00002-0. PMid:12915216.

KELEN, M. and TEPE, B., 2008. Chemical composition, antioxidant and antimicrobial properties of the essential oils of three Salvia species from Turkish Flora. Bioresource Technology, vol. 99, no. 10, pp. 4096-4104. http://dx.doi.org/10.1016/j. biortech.2007.09.002. PMid:17936619.

KOSAR, M., DORMAN, H.J.R. and HILTUNEN, R., 2005. Effect of an acid treatment on the phytochemical and antioxidant characteristics of extracts from selected Lamiaceae species. Food Chemistry, vol. 91, no. 3, pp. 525-533. http://dx.doi.org/10.1016/j. foodchem.2004.06.029.

KURSAT, M., EMRE, I., YILMAZ, O. and ERECEVIT, P., 2011. Antioxidant and antimicrobial activity in the seeds of Origanum vulgare L. subsp. gracile (C. Koch) Ietswaart and Origanum acutidens (Hand.-Mazz.) Ietswaart from Turkey. Grasas y Aceites, vol. 62, no. 4, pp. 410-417. http://dx.doi.org/10.3989/gya.113610.

LÓPEZ-CERVANTES, J., SÁNCHEZ-MACHADO, D.I. and RÍOS-VÁZQUEZ, N.J., 2006. High-performance liquid chromatography method for the simultaneous quantification of retinol, $\alpha$-tocopherol, and cholesterol in shrimp waste hydrolysate. Journal of Chromatography A, vol. 1105, no. 1-2, pp. 135-139. http://dx.doi.org/10.1016/j.chroma.2005.08.010. PMid:16439259.

LIS-BALCHIN, M. and DEANS, S.G., 1997. Bioactivity of selected plant essential oils against Listeria monocytogenes. Journal of Applied Bacteriology, vol. 82, no. 6, pp. 759-762. http://dx.doi. org/10.1046/j.1365-2672.1997.00153.x. PMid:9202441. 
LIYANA-PATHIRANA, C.M. and SHAHIDI, F., 2005. Antioxidant activity of commercial soft and hard wheat (Triticum aestivum L.) as affected by gastric $\mathrm{pH}$ conditions. Journal of Agricultural and Food Chemistry, vol. 53, no. 7, pp. 2433-2440. PMid:15796575.

MAHBOUBI, M. and HAGHI, G., 2008. Antimicrobial activity and chemical composition of Mentha pulegium L. essential oil. Journal of Ethnopharmacology, vol. 119, no. 2, pp. 325-327. http://dx.doi.org/10.1016/j.jep.2008.07.023. PMid:18703127.

MAZZINI, F., GALLI, F. and SALVADORI, P., 2006. Vitamin E metabolites: synthesis of [D2]- and [D3]- $\gamma$-CEHC. European Journal of Organic Chemistry, vol. 2006, no. 24, pp. 5588-5593. http://dx.doi.org/10.1002/ejoc.200600652.

MORENO, L., BELLO, R., PRIMO-YUFERA, E. and ESPLUGUES, J., 2002. Pharmacological properties of the methanol extract from Mentha suaveolens Ehrh. Phytotherapy Research, vol. 16, suppl. 1, pp. 10-13. http://dx.doi.org/10.1002/ptr.744. PMid:11933132.

MOTAMED, M.S. and NAGHIBI, F., 2010. Antioxidant activity of some edible plants of the Turkmen Sahra region in northern Iran. Food Chemistry, vol. 119, no. 4, pp. 1637-1642. http:// dx.doi.org/10.1016/j.foodchem.2009.09.057.

OKE, F., ASLIM, B., OZTURK, S. and ALTUNDAG, S., 2009. Essential oil composition, antimicrobial and antioxidant activities of Satureja cuneifolia Ten. Food Chemistry, vol. 112, no. 4, pp. 874-878. http://dx.doi.org/10.1016/j.foodchem.2008.06.061

PANDINI, J.A., PINTO, F.G.S., SCUR, M.C., SANTANA, C.B., COSTA, W.F. and TEMPONI, L.G., 2018. Chemical composition, antimicrobial and antioxidant potential of the essential oil of Guarea kunthiana A. Juss. Brazilian Journal of Biology $=$ Revista Brasileira de Biologia, vol. 78, no. 1, pp. 53-60. http://dx.doi. org/10.1590/1519-6984.04116. PMid:28793029.

PEREIRA, C., LI, D. and SINCLAIR, A.J, 2001. The alpha-linolenic acid content of green vegetablers commonly available in Australia. International Journal for Vitamin and Nutrition Research, vol. 71, no. 4, pp. 223-228. http://dx.doi.org/10.1024/0300-9831.71.4.223. PMid:11582857.

RAJARAM, S., 2014. Health benefits of plant-derived a-linolenic acid. The American Journal of Clinical Nutrition, vol. 100, suppl. 1, pp. 443S-448S. http://dx.doi.org/10.3945/ajcn.113.071514. PMid:24898228.

RAO, K.S. and LAKSHMINARAYANA, G., 1988. Lipid class and fatty acid compositinos of edible tissues of Peucedanum graveolens, Mentha arvensis and Colocasia esculenta plants. Journal of Agricultural and Food Chemistry, vol. 36, no. 3, pp. 475-478. http://dx.doi.org/10.1021/jf00081a017.

RAVINASKAR, P., REDDY, A.A., NAGALKASMI, B., KOUSHIK, O.S., KUMAR, B.V. and ANVITH, P.S., 2015. The comprehensive review on fat soluble vitamins. IOSR Journal of Pharmacy, vol. 5, no. 11, pp. 12-28.

REYNOLDS, J.E.F., 1996. Martindale-the extra pharmacopeia. 31 st ed. London: Royal Pharmaceutical Society of Great Britain.

RIZVI, S., RAZA, S.T., AHMED, F., AHMAD, A., ABBAS, S. and MAHDI, F., 2014. The role of vitamin e in human health and some diseases. Sultan Qaboos University Medical Journal, vol. 14, no. 2, pp. e157-e165. PMid:24790736.

SAHIN, F., KARAMAN, I., GULLUCE, M., OĞÜTÇÜ, H., SENGÜL, M., ADIGÜZEL, A., OZTÜRK, S. and KOTAN, R., 2003. Evaluation of antimicrobial activities of Satureja hortensis L. Journal of Ethnopharmacology, vol. 87, no. 1, pp. 61-65. http:// dx.doi.org/10.1016/S0378-8741(03)00110-7. PMid:12787955.
SÁNCHEZ-MACHADO, D.I., LÓPEZ-HERNÁNDEZ, J. and PASEIRO-LOSADA, P., 2002. High-performance liquid chromatographic determination of a-tocopherol in macroalgae. Journal of Chromatography A, vol. 976, no. 1-2, pp. 277-284. http:// dx.doi.org/10.1016/S0021-9673(02)00934-2. PMid:12462619.

SATIL, F. and KAYA, A., 2007. Leaf anatomy and hairs of Turkish Satureja L. (Lamiaceae). Acta Biologica Cracoviensia: Series Botanica, vol. 49, no. 1, pp. 67-76.

SCHERER, R., LEMOS, M.F., LEMOS, M.F., MARTINELLI, G.C., MARTINS, J.D.L. and SILVA, A.G., 2013. Antioxidant and antibacterial activities and composition of Brazilian spearmint (Mentha spicata L.). Industrial Crops and Products, vol. 50, pp. 408-413. http://dx.doi.org/10.1016/j.indcrop.2013.07.007.

SHAHIDI, F. and AMBIGAIPALAN, P., 2015. Phenolics and polyphenolics in foods, beveragesand spices: antioxidant activity and health effects: a review. Journal of Functional Foods, vol. 18, pp. 820-897. http://dx.doi.org/10.1016/j.jff.2015.06.018.

SIALVERA, T.E., POUNIS, G.D., KOUTELIDAKIS, A.E., RICHTER, D.J., YFANTI, G., KAPSOKEFALOU, M., GOUMAS, G., CHIOTINIS, N., DIAMANTOPOULOS, E. and ZAMPELAS, A., 2012. Phytosterols supplementation decreases plasma small and dense LDL levels in metabolic syndrome patients on a westernized type diet. Nutrition, Metabolism, and Cardiovascular Diseases, vol. 22, no. 10, pp. 843-848. http://dx.doi.org/10.1016/j. numecd.2010.12.004. PMid:21316934.

SINGH, M., 2005. Essential fatty acids, DHA and human brain. Indian Journal of Pediatrics, vol. 72, no. 3, pp. 239-242. http:// dx.doi.org/10.1007/BF02859265. PMid:15812120.

SINGH, R., SHUSHNI, M.A.M. and BELKHEIR, A., 2015. Antibacterial and antioxidant activities of Mentha piperita L. Arabian Journal of Chemistry, vol. 8, no. 3, pp. 322-328. http:// dx.doi.org/10.1016/j.arabjc.2011.01.019.

SKOULA, M., GRAYER, R.J. and KITE, G.C., 2005. Surface flavonoids in Satureja thymbra and Satureja spinosa (Lamiaceae). Biochemical Systematics and Ecology, vol. 33, no. 5, pp. 541-544. http://dx.doi.org/10.1016/j.bse.2004.10.003.

STRINGARO, A., COLONE, M. and ANGIOLELLA, L., 2018. Antioxidant, antifungal, antibiofilm, and cytotoxic activities of Mentha spp. essential oils. Medicines, vol. 5, no. 4, pp. 1-15. http://dx.doi.org/10.3390/medicines5040112. PMid:30347861.

SYTAR, O., HEMMERICH, I., ZIVCAK, M., RAUH, C. and BRESTIC, M., 2018. Comparative analysis of bioactive phenolic compounds composition from 26 medicinal plants. Saudi Journal of Biological Sciences, vol. 25, no. 4, pp. 631-641. http://dx.doi. org/10.1016/j.sjbs.2016.01.036. PMid:29740227.

TANG, K.S.C., KONCZAK, I. and ZHAO, J., 2016. Identification and quantification of phenolics in Australian native mint (Mentha australis R. Br.). Food Chemistry, vol. 192, pp. 698-705. http:// dx.doi.org/10.1016/j.foodchem.2015.07.032. PMid:26304400.

TASAN, M., BILGIN, B., GECGEL, U. and DEMIRCI, A.S., 2006. Phytosterols as functional food ingredients. Tekirdag Ziraat Fakültesi Dergisi, vol. 3, no. 2, pp. 153-159.

TAWAHA, K., ALALI, F.Q., GHARAJBEH, M., MOHAMMED, M. and EL-ELIMAT, T., 2007. Antioxidant activity and total phenolic content of selected Jordanian plant species. Food Chemistry, vol. 104, no. 4, pp. 1372-1378. http://dx.doi.org/10.1016/j. foodchem.2007.01.064

TEPE, B. and CILKIZ, M., 2016. A pharmacological and phytochemical overview on Satureja. Pharmaceutical Biology, 
vol. 54, no. 3, pp. 375-412. http://dx.doi.org/10.3109/13880209 .2015.1043560. PMid:25955956.

TEPE, B., 2008. Antioxidant potentials and rosmarinic acid levels of the methanolic extracts of Salvia virgata (Jacq), Salvia staminea (Montbret\& Aucher ex Bentham) and Salvia verbenaca (L.) from Turkey. Bioresource Technology, vol. 99, no. 6, pp. 1584-1588. http://dx.doi.org/10.1016/j.biortech.2007.04.008. PMid:17531471.

TULUKCU, E., 2011. herbal tea fatty acid contents of some medicinal plants grown in Konya, Turkey. Asian Journal of Chemistry, vol. 23, no. 3, pp. 1369-1372.

UNVER, A., ARSLAN, D., OZCAN, M.M. and AKBULUT, M., 2009. Phenolic content and antioxidant activity of some species. World Applied Sciences Journal, vol. 6, no. 3, pp. 373-377.

VALDIVIESO-UGARTE, M., GOMEZ-LLORENTE, C., PLAZA-DÍAZ, J. and GIL, Á., 2019. Antimicrobial, antioxidant, and immunomodulatory properties of essential oils: a systematic review. Nutrients, vol. 11, no. 11, e2786. http://dx.doi.org/10.3390/ nu11112786. PMid:31731683.

VITANZA, L., MACCELLI, A., MARAZZATO, M., SCAZZOCCHIO, F., COMANDUCCI, A., FORNARINI, S., CRESTONI, M.E., FILIPPI, A., FRASCHETTI, C., RINALDI, F., ALEANDRI, M., GOLDONI, P., CONTE, M.P., AMMENDOLIA, M.G. and LONGHI, C., 2019. Satureja montana L. essential oil and its antimicrobial activity alone or in combination with gentamicin. Microbial Pathogenesis, vol. 126, pp. 323-331. http://dx.doi. org/10.1016/j.micpath.2018.11.025. PMid:30458252.

YADEGARINIA, D., GACHKAR, L., REZAEI, M.B., TAGHIZADEH, M., ASTANEH, S.A. and RASOOLI, I., 2006.
Biochemical activities of Iranian Mentha piperita L. and Myrtus communis L. essential oils. Phytochemistry, vol. 67, no. 12, pp. 1249-1255. http://dx.doi.org/10.1016/j.phytochem.2006.04.025. PMid:16777154.

YESILOGLU, Y., SIT, L. and KILIC, I., 2013. In vitro antioxidant activity and total phenolic content of various extracts of Satureja hortensis L. collected from Turkey. Asian Journal of Chemistry, vol. 25 , no. 15 , pp. 8311-8316. http://dx.doi.org/10.14233/ ajchem.2013.14731.

ZAHEDIFAR, M.I. and NAJAFIAN, S.H., 2015. Combined effect of soil applied iron and sulfur fertilisers on monoterpene content and antioxidant activity of Satureja hortensis L. extract. Pertanika Journal of Tropical Agricultural Science, vol. 38, no. 3, pp. 361-374.

ZELJKOVIĆ, S.Ć., TOPČAGIĆ, A., POŽGAN, F., ŠTEFANE, B., TARKOWSKI, P. and MAKSIMOVIĆ, M., 2015. Antioxidant activity of natural and modified phenolic extracts from Satureja montana L. Industrial Crops and Products, vol. 76, pp. 1094-1099. http://dx.doi.org/10.1016/j.indcrop.2015.08.009.

ZHENG, W. and WANG, S.Y., 2001. Antioxidant activity and phenolic compounds in selected herbs. Journal of Agricultural and Food Chemistry, vol. 49, no. 11, pp. 5165-5170. http://dx.doi. org/10.1021/jf010697n. PMid:11714298.

ZU, Y.G., LI, C.Y., FU, Y.J. and ZHAO, C.J., 2006. Simultaneous determination of catechin, rutin, quercetin kaempferol and isorhamnetin in the extract of sea buckthorn (Hippophae rhamnoides L.) leaves by RP-HPLC with DAD. Journal of Pharmaceutical and Biomedical Analysis, vol. 41, no. 3, pp. 714-719. http://dx.doi. org/10.1016/j.jpba.2005.04.052. PMid:16520013. 